\title{
DISTRIBUSI FREKUENSI FAKTOR PENYEBAB KEJADIAN ASFIKSIA PADA BAYI BARU LAHIR DI RS. FADHILLAH KOTA PRABUMULIH TAHUN 2017
}

\author{
Maria Septiana \\ Akademi Kebidanan Budi Mulia Prabumulih
}

\section{Informasi Artikel :}

Diterima : $\quad$ September 2018

Disetujui : $\quad$ Desember 2018

"Korespondensi Penulis :

maria.septiana@rocketmail.com

\begin{abstract}
A B S T R A K
Komplikasi yang menjadi penyebab kematian bayi baru lahir yang terbanyak yaitu asfiksia. penyebab terjadinya asfiksia ada 3 yaitu, faktor ibu (preeklamsi dan eklamsia, perdarahan abnormal yang disebabkan karena plasenta previa atau solusio plasenta, partus lama, demam selama persalinan, infeksi berat, kehamilan post matur, usia ibu kurang dari 20 tahun atau lebih dari 35 tahun), faktor bayi (bayi prematur, persalinan sulit, kelainan konginetal, air ketuban bercampur mekonium), faktor tali pusat (lilitan tali pusat, tali pusat pendek, simpul tali pusat dan prolapsus tali pusat) Metode penelitian : Pengambilan data dalam penelitian ini menggunakan data sekunder dengan pendekatan retrospektif. Hasil Penelitian : Faktor penyebab kejadian asfiksia pada bayi baru lahir berdasarkan faktor ibu yaitu mayoritas terjadi pada usia ibu 20-35 tahun sebanyak $16(51,6 \%)$, paritas $10(32,3 \%)$, umur kehamilan $18(58,1 \%)$ dan berdasarkan faktor dari bayi yaitu mayoritas terjadi pada berat lahir bayi >2500 gram sebanyak $12(38,7 \%)$, dan jenis persalinan yang mengalami asfiksia pada persalinan normal sebanyak $10(32,3 \%)$. Kesimpulan : Faktor penyebab kejadian asfiksia pada bayi baru lahir di RS Fadhilah Kota Prabumulih yaitu dari faktor ibu yaitu mayoritas terjadi pada usia ibu 20-35 tahun, paritas multipara, umur kehamilan 37-42 minggu dan dari faktor bayi yaitu bayi dengan berat lahir $>2500$ gram dan jenis persalinan normal.
\end{abstract}

Kata Kunci : Asfiksia, Bayi baru lahir, faktor penyebab.

\begin{abstract}
Asphyxia is one of the complications that become the largest cause of death. Therevare three cause of asphyxia, namely, maternal factors (preeclampsia and eclampsia, abnormal bleeding caused by placenta previa or placental abruption, prolonged labor, fever during labor, severe infections, pregnancy post mature, maternal age less than 20 years old or over 35 years ), factor infants (premature babies, difficult delivery, konginetal disorders, meconium-stained amniotic fluid mixes), factor umbilical cord (umbilical cord loops, short umbilical cord, knot the cord and umbilical cord prolapse). Athere are 31 cose of asphyxia in Fadhilah Hospital. Objective : Knowing the factors that cause asphyxia in newborns at RS Fadhilah Prabumulih City. Methods : Collecting data in this study using secondary data with retrospective approach Result: Factors that cause asphyxia in newborns by maternal factors that occur in the majority of maternal age 20-35 years as many as 16 (51.6\%), parity $10(32.3 \%)$, gestational age $18(58.1 \%)$ and by factors of which the majority occur in infants birth weight $>2500 \mathrm{~g}$ were $12(38.7 \%)$, and the type of delivery that asphyxiated the normal labor as much as 10 (32.3\%). Conclusion : Factors that cause asphyxia in newborns at PKU Muhammadiyah Hospital in Bantul 2016 ie from the maternal factors that occur in the majority of maternal age 20-35 years, multiparas parity, gestational age of 37-42 weeks and infant factors that infants with birth weight $>2500$ gram and type of normal deliveries.
\end{abstract}

Keyword : Asphyxia, Newborns, factor 


\section{PENDAHULUAN}

Neonatal dengan komplikasi adalah neonatal dengan penyakit dan atau kelainan yang dapat menyebabkan kecacatan dan atau kematian, seperti asfiksia, ikterus, hipotermia, tetanus neonatorum, infeksi/sepsis, trauma lahir, BBLR, sindroma gangguan pernafasan, dan kelainan konginetal maupun yang sudah termasuk klasifikasi kuning dan merah pada pemeriksaan dengan Manajemen Terpadu Bayi Muda (MTBM). Komplikasi yang menjadi penyebab kematian yang terbanyak yaitu asfiksia (27\%), bayi berat lahir rendah (29\%) dan infeksi (6,7\%) (herianto, dkk, 2012). Capaian penanganan neonatal dengan komplikasi mengalami peningkatan dari tahun 2013 yang sebesar 51,47\% menjadi 59,68\% pada tahun 2014 (KeMenKes RI, 2014).

Menurut Marmi dan Kukuh (2012), penyebab terjadinya asfiksia ada 3 yaitu, factor ibu, factor bayi dan factor tali pusat. Faktor ibu terdiri dari preeklamsi dan eklamsia, perdarahan abnormal yang disebabkan karena plasenta previa atau solusio plasenta, partus lama, demam selama persalinan, infeksi berat, kehamilan post matur, usia ibu kurang dari 20 tahun atau lebih dari 35 tahun. Faktor bayi terdiri dari bayi prematur, persalinan sulit, kelainan konginetal, air ketuban bercampur mekonium. Sedangkan faktor tali pusat terdiri dari lilitan tali pusat, tali pusat pendek, simpul tali pusat dan prolapsus tali pusat. Asfiksia berarti hipoksia yang progresif, penimbunan $\mathrm{CO}_{2}$ dan asidosis. Bila proses ini berlangsung terlalu jauh dapat mengakibatkan kerusakan otak atau kematian. Bayi yang dalam keadaan asfiksia dan pulih kembali harus diperkirakan kemungkinannya menderita cacat mental seperti epilepsy dan bodoh pada masa mendatang (Respatiningrum, dkk, 2012).

Jika skor APGAR tetap dibawah 3 dalam tes berikutnya (10, 15 atau 30 menit), maka ada resiko bahwa anak tersebut dapat mengalami kerusakan syaraf jangka panjang. Juga ada resiko kecil tapi signifikan akan kerusakan otak. Namun demikian, tujuan tes APGAR adalah untuk menentukan dengan cepat apakah bayi yang baru lahir tersebut membutuhkan penanganan medis segera, dan tidak didesain untuk memberikan prediksi jangka panjang akan kesehatan bayi tersebut. Asfiksia jika berlangsung terlalu lama dapat menimbukan perdarahan otak, kerusakan otak dan kemudian keterlambatan tumbuh kembang. Asfiksia juga dapat menimbulkan cacat seumur hidup seperti buta, tuli, cacat otak dan kematian. Asfiksia adalah salah satu faktor yang menyebabkan kematian neonatal, sedangkan bayi yang dapat bertahan hidup akibat asfiksia dapat mengalamai komplikasi neurologis seperti epilepsy, cerebral palsy dan keterlambatan perkembangan. Asfiksia juga bisa mengakibatkan cedera otak parah, cedera otak parah membuat perkembangan kognitif terhambat, perkembangan motorik tertunda dan cerebral palsy (Jurnal Pediatri, 2013).

Umumnya di Negara berkembang, 25\% kematian bayi dan 50\% kematian neonatal disebabkan oleh infeksi pada tali pusat, sepsis sampai dengan tetanus (Kandun, 2009). Berdasarkan penelitian WHO diseluruh dunia terdapat kematian bayi sebesar 56 per 10.000 menjadi sekitar 280.000 terjadi setiap 18-20 menit sekali. Penyebab kematian tersebut antara lain karena asfiksia neonatorum 40-60\%, infeksi 24$34 \%$. Infeksi tersebut disebabkan karena perawatan tali pusat yang kurang hygienis (Manuaba, 2008). Hasil laporan dari petugas Survailans Depkes RI pada tahun 1992-1996 ditemukan bahwa kasus Tetanus Neonatorum pada tahun 1993-1996 terjadi peningkatan dengan kisaran 10,8-55\%. Bila dilihat penyebarannya menurut provinsi kasus tertinggi terdapat di Provinsi Jawa Barat sebesar 246 kasus, menyusul Jawa Tengah dengan 94 kasus, Jawa Timur sebesar88 kasus, Ponorogo kematian bayi di tahun 2009 sebanyak 116 anak, tahun 2010 sebanyak 168 anak, dan tahun 2011 sebanyak 178 anak (Dinkes Ponorogo, 2012).

Sustainable Development Goals (SDGs) menargetkan angka kematian bayi dan balita masing-masing maksimum 12 dan 25 setiap1.000 kelahiran hidup di tahun 2030. Akan tetapi, berdasarkan data SDKI 2012 angka kematian bayi dan balita, 32 dan 40 per 1.000 kelahiran hidup (SHRS dan Agenda, 2015). Sedangkan Angka Kelahiran Bayi dilaporkan di Sumatera Selatan tahun 2014 adalah 3,7 per 1000 kelahiran hidup lebih tinggi dari tahun 2013 sebesar 2,8 per 1000 kelahiran hidup. Sebanyak lima kasus dari kasus yang dilaporkan. Maka hal tersebut perlu mendapatkan perhatian bagi pelaksana program baik di Tingkat Provinsi maupun Kabupaten kota. Angka kematian bayi di Provinsi Sumatra Selatan dalam beberapa tahun terakhir masih sulit ditentukan, karena tidak ada survey atau penelitian khusus (Dinas Kesehatan Provinsi Sumatra Selatan, 2014).

Berdasarkan data dari Dinas Kesehatan Kota Prabumulih (Dinkes) pada tahun 2015 Angka Kematian Bayi (AKB) sebanyak 11 kasus yaitu 3 kasus asfiksia, 2 kasus BBLR dan 6 kasus penyebab lainnya. Pada tahun 2016 sebanyak 17 kasus yaitu 3 kasus asfiksia, 9 kasus BBLR dan 5 kasus penyebab lainya. Pada tahun 2017 sebanyak 11 kasus yaitu 2 
Jurnal Kebidanan : Jurnal Medical Science Ilmu Kesehatan Akademi Kebidanan Budi Mulia Palembang Volume.8 No.2, Desember 2018

kasus asfiksia, 4 kasus BBLR dan 5 kasus penyebab lainya (Dinkes Kota Prabumulih, 2017).

Berdasarkan data yang didapat dari RS. Fadhilah Kota Prabumulih angka kejadian asfiksia pada bayi baru lahir pada tahun 2015 sebanyak 57 kasus, pada tahun 2016 sebanyak 112 kasus. Pada tahun 2017 sebanyak 21 kasus dan pada tahun 2018 sampai bulan mei sebanyak 8 kasus. (Medical Record RS. Fadhilah, 2017).

\section{METODE PENELITIAN}

Penelitian ini menggunakan jenis penelitian Observasional Analitik dengan rancangan penelitian case control yaitu umur kehamilan beresiko yang mengalami asfiksia 28 responen (70\%), umur kehamilan yang tidak beresiko dan banyinya tidak mengalami asfksia 22 responden (55\%).

\section{HASIL PENELITIAN}

1. Hasil Penelitian

a. Distribusi frekuensi faktor penyebab kejadian asfiksia pada bayi baru lahir berdasarkan factor ibu (usia ibu, paritas, usia kehamilan) di RS Fadhilah Kota Prabumulih Tahun 2017.

Tabel 1 Distribusi Frekuensi penyebab kejadian asfiksia berdasarkan faktor ibu Di RS Fadhilah Kota Prabumulih Tahun 2017

\begin{tabular}{lcc}
\hline \multicolumn{1}{c}{ Faktor Ibu } & Frekuensi & Persentasi (\%) \\
\hline Umur & 2 & 6,5 \\
$<20$ Tahun & 27 & 87,1 \\
20 - 35 Tahun & 2 & 6,5 \\
$>35$ tahun & 31 & 100 \\
\hline Total & 14 & \\
\hline Paritas & 16 & 45,2 \\
Primipara & 1 & 51,6 \\
Multipara & 31 & 3,2 \\
Grademultipara & 1 & 100 \\
\hline Total & 30 & 3,2 \\
\hline Umur Kehamilan & 31 & 96,8 \\
<37 minggu & & 100 \\
$37-42$ minggu & & \\
\hline Total & &
\end{tabular}

Berdasarkan tabel. 1 menunjukkan bahwa kejadian asfiksia sebagian besar disebabkan oleh faktor ibu yaitu ibu yang berumur 20-35 tahun sebanyak 27 ibu $(87,1 \%)$, memiliki paritas lebih dari 1 anak atau multipara sebanyak 16 ibu $(51,6 \%)$ dan terjadi pada usia kehamilan37-42 sebanyak 30 ibu $(96,8 \%)$.

b. Faktor penyebab kejadian asfiksia pada bayi baru lahir berasarkan faktor bayi (berat lahir bayi, jenis persalinan) di RS Fadhilah Kota Prabumulih Tahun 2017.

Tabel. 2 Distribusi Frekuensi penyebab kejadian asfiksia berdasarkan faktor bayi Di RS Fadhilah Kota Prabumulih Tahun 2017

\begin{tabular}{lcc}
\hline \multicolumn{1}{c}{ Faktor bayi } & Frekuensi & Persentase (\%) \\
\hline Berat lahir bayi & & 25.8 \\
1500-2500 Gram & 8 & 74.2 \\
>2500 gran & 23 & 100.0 \\
\hline Total & 31 & \\
\hline Jenis persalinan & & 48.4 \\
Normal & 15 & 32.3 \\
SC & 10 & 19.4 \\
VE & 6 & 100.0 \\
\hline Total & 31 & \\
\hline
\end{tabular}


Jurnal Kebidanan : Jurnal Medical Science Ilmu Kesehatan Akademi Kebidanan Budi Mulia Palembang Volume.8 No.2, Desember 2018

Berdasarkan tabel. 2 menunjukkan bahwa penyebab kejadian asfiksia sebagian besar disebabkan oleh faktor bayi yaitu bayi dengan berat lahir $>2500$ gram sebanyak 23 responden $(74,2 \%)$, dan dari jenis persalinan mayoritas jenis persalinan normal sebanyak 15 responden $(48,4 \%)$.

Tabel. 3 Tabulasi Silang Antara Faktor Penyebab Kejadian Asfiksia Dengan Asfiksia

\begin{tabular}{|c|c|c|c|c|c|c|c|c|}
\hline \multirow[t]{3}{*}{ Faktor Penyebab } & \multicolumn{5}{|c|}{ Asfiksia } & \multicolumn{3}{|c|}{ Jumlah } \\
\hline & \multicolumn{2}{|l|}{ Ringan } & \multicolumn{2}{|l|}{ Sedang } & \multicolumn{2}{|l|}{ Berat } & & \\
\hline & f & $\%$ & $\mathbf{F}$ & $\%$ & f & $\%$ & $\mathbf{F}$ & $\%$ \\
\hline \multicolumn{9}{|l|}{ Faktor Ibu } \\
\hline \multicolumn{9}{|l|}{ Usia Ibu } \\
\hline$<20$ tahun & 0 & 0,0 & 1 & 3,2 & 1 & 3,2 & 2 & 6,5 \\
\hline $20-35$ tahun & 2 & 6,5 & 9 & 29,0 & 16 & 51,6 & 27 & 87,1 \\
\hline$>35$ tahun & 0 & 0,0 & 1 & 3,2 & 1 & 3,2 & 2 & 6,5 \\
\hline Total & 2 & 6,5 & 11 & 35,5 & 18 & 51,8 & 31 & 100 \\
\hline \multicolumn{9}{|l|}{ Paritas } \\
\hline Primipara & 0 & 0,0 & 4 & 12,9 & 10 & 32.3 & 14 & 45.2 \\
\hline Mltipara & 2 & 6,5 & 7 & 22,6 & 7 & 22.6 & 16 & 51.6 \\
\hline grandemultipara & 0 & 0,0 & 0 & 0,0 & 1 & 3.2 & 1 & 3.2 \\
\hline Total & 2 & 6,5 & 11 & 35,5 & 18 & 58.1 & 31 & 100 \\
\hline \multicolumn{9}{|l|}{ Usia kehamilan } \\
\hline$<37$ minggu & 0 & 0.0 & 1 & 3.2 & 0 & 0.0 & 1 & 3.2 \\
\hline 37-42 minggu & 2 & 6.5 & 10 & 32.3 & 18 & 58.1 & 30 & 96.8 \\
\hline Total & 2 & 6,5 & 11 & 35,5 & 18 & 58.1 & 31 & 100 \\
\hline
\end{tabular}

\section{Faktor bayi}

Berat lahir bayi

\begin{tabular}{lcccccccc} 
1500-2500 Gram & 0 & 0.0 & 2 & 6.5 & 6 & 19.4 & 8 & 25.8 \\
$>$ 2500 Gram & 2 & 6.5 & 9 & 29.0 & 12 & 38.7 & 23 & 74.2 \\
\hline Total & 2 & 6,5 & 11 & 35,5 & 18 & 58.1 & 31 & 100 \\
\hline
\end{tabular}

Jenis persalinan

$\begin{array}{lllllllll}\text { Normal } & 0 & 0.0 & 5 & 16.1 & 10 & 32.3 & 15 & 48.4\end{array}$

$\begin{array}{lllllllll}\mathrm{SC} & 1 & 3.2 & 4 & 12.9 & 5 & 16.1 & 10 & 32.3\end{array}$

\begin{tabular}{|c|c|c|c|c|c|c|c|c|}
\hline VE & 1 & 3.2 & 2 & 6.5 & 3 & 9.7 & 7 & 19.4 \\
\hline Total & 2 & 6,5 & 11 & 35,5 & 18 & 58.1 & 31 & 100 \\
\hline
\end{tabular}

Berdasarkan tabel. 3 menunjukkan bahwa faktor penyebab asfiksia berdasarkan faktor ibu yaitu mayoritas terjdi pada usia ibu 20-35 tahun

sebanyak $16(51,6 \%)$ dan mengalami asfiksi berat $18(58,1 \%)$ dari faktor paritas yang menyebabkan asfiksia yaitu ibu multipara sebanyak $10(32,3 \%)$ dan mengalami asfiksia berat sebanyak 18 $(58,1 \%)$, dari faktor ibu yang mengalami asfiksia pada bayi baru lahir pada usia kehamilan $37-42$ minggu sebanyak $18(58,1 \%)$ responden dan mengalami asfiksia berat sebanyak $18(58,1 \%)$. Dari faktor bayi mayoritas yang mengalami asfiksia dari berat lahir bayi yaitu bayi dengan berat $>2500$ gram sebanyak $12(38,7 \%)$, mengalami asfiksia berat yaitu sebanyak 18 $(58,1 \%)$, sedangkan dari jenis persalinan yang mengalami asfiksia pada persalinan normal sebanyak $10(32,3 \%)$ dan mengalami asfiksia berat sebanyak $18(58,1 \%)$.

\section{PEMBAHASAN}

1. Faktor Penyebab Kejadian Asfiksia Berdasarkan Faktor Ibu

a. Usia ibu

Hasil penelitian menunjukkan bahwa mayoritas faktor penyebab kejadian asfiksia disebabkan oleh ibu yang berumur 20-35 tahun yaitu sebanyak 27 responden, tetapi dari 31 responden yang diteliti terdapat 4 responden yang berumur $<20$ tahun dan $>35$ tahun. 
Dari segi kesehatan ibu yang berumur $<20$ tahun dan >35 tahun tidak sebaik seperti saat ibu berumur 20-35 tahun. Kehamilan di usia muda atau remaja di bawah usia 20 tahun akan mengakibatkan rasa takut terhadap kehamilan dan persalinan, hal ini disebabkan pada usia ini ibu belum siap untuk mempunyai anak dan alat-alat reproduksi ibu belum siap untuk hamil sedangkan umur ibu $>35$ tahun merupakan umur yang tidak reproduktif atau umur tersebut dalam risiko tinggi kehamilan. Kehamilan diusia tua akan menimbulkan kecemasan terhadap kehamilan dan persalinan serta alat-alat reproduksi ibu terlalu tua untuk hamil. Umur pada waktu hamil sangat berpengaruh pada kesiapan ibu untuk menerima tanggung jawab sebagai seorang ibu sehingga kualitas sumber daya manusia makin meningkat dan kesiapan untuk menyehatkan generasi penerus dapat terjamin. (Prawirohardjo, 2007).

Penelitian yang dilakukan oleh Revrely yang berjudul "Faktor-Faktor Yang Berhubungan Dengan Kejadian Asfiksia Neonatorum Di RSUP Prof. Dr. R. D. Kandou Manado" menyatakan bahwa hubungan umur ibu dengan asfiksia neonatorum menunjukkan angka yang paling besar presentasinya adalah umur ibu yang berisiko ( $<20$ tahun; $>35$ tahun) dengan bayi yang asfiksia yaitu 13 bayi atau 52\%. Berarti umur ibu yang berisiko (< 20 tahun; > 35 tahun) mempunyai peluang 1,563 kali bayinya mengalami asfiksia dari pada umur ibu yang tidak berisiko (20-35 tahun) (Revrely, 2011).

Hasil penelitian ini berbeda dengan hasil penelitian lain sebelumnya, penelitian ini menyatakan bahwa faktor penyebab asiksia mayoritas terjadi pada ibu usia 20-35 tahun, sedangkan pada penelitian lain mayoritas terjadi pada usia ibu kurang dari 20 tahun dan pada usia lebih dari 35 tahun.

\section{b. Paritas}

Faktor paritas juga menyebabkan terhadap kejadian asfiksia. Hasil penelitian menunjukkan bahwa ibu multipara sebanyak 16 responden $(51,6 \%)$ memiliki resiko lebih besar melahirkan bayi dengan asfiksia berat $(58,1 \%)$. Hampir sebagian dari jumlah responden adalah ibu primipara yaitu sebanyak 14 ibu $(45,2 \%)$, Paritas 2-3 merupakan paritas paling aman ditinjau dari sudut kematian maternal. Paritas 1 dan $\geq 4$ mempunyai angka kematian maternal yang disebabkan perdarahan pasca persalinan lebih tinggi. Paritas yang rendah (paritas satu) menunjukan ketidaksiapan ibu dalam menangani komplikasi yang terjadi dalam kehamilan, persalinan dan nifas. Paritas 1 beresiko karena ibu belum siap secara medis maupun secara mental. Hasil penelitian bahwa primiparity merupakan faktor risiko yang mempunyai hubungan yang kuat terhadap mortalitas asfiksia (Prawirohardjo, 2007)

Penelitian yang dilakukan oleh Selli, F.M dengan judul "Faktor-Faktor Yang Berhubungan Dengan Kejadian Asfiksia Neonatorum Di RSUP. DR. M. Djamil Padang" menyatakan bahwa lebih dari separuh (55\%) paritas 1 dan $\geq 4$ melahirkan dengan bayi asfiksia dibandingkan dengan paritas 2-3.

Hasil penelitian ini berbeda dengan hasil penelitian lain sebelumnya, penelitian ini menyatakan bahwa faktor penyebab asiksia mayoritas terjadi pada ibu parutas yaitu multipara, sedangakan pada penelitian lain mayoritas terjadi pada ibu paritas primipara dan grandemultipara.

\section{c. Umur kehamilan}

Umur kehamilan merupakan salah satu faktor risiko yang mempunyai pengaruh terhadap kejadian asfiksia pada bayi baru lahir. Hasil penelitian menunjukkan bahwa faktor ibu yang mengalami asfiksia pada bayi baru lahir pada usia kehamilan 37-42 minggu sebanyak 30 responden $(96,8 \%)$ dan mengalami asfiksia berat sebanyak $18(58,1 \%)$. Dari 31 responden yang diteliti masih terdapat 1 responden yang melahirkan bayi dengan asfiksia pada usia kehamilan <37 minggu.

Umur kehamilan atau usia gestasi (gestational age) adalah ukuran lama waktu seorang janin berada dalam rahim. Usia janin dihitung dalam minggu dari hari pertama menstruasi terakhir (HPMT) ibu sampai hari kelahiran (Kamus Kesehatan, 2011). Menentukan usia kehamilan sangat penting untuk memperkirakan persalinan. Rumus Naegle menggunakan usia kehamilan yang berlangsung selama 288 hari. Perkiraan kelahiran dihitung dengan menentukan hari pertama haid terakhir yang kemudian ditambah 288 hari (Manuaba, 2010).

Kematian perinatal yang tinggi $(70 \%)$ disebabkan oleh persalinan <37 minggu (persalinan premature). Persalinan dengan bayi premature, organ vitalnya belum berkembang dengan sempurna sehingga menyebabkan ia belum mampu untuk hidup diluar kandungan, 
sehingga sering mengalami kegagalan adaptasi yang dapat menimbulkan morbiditas bahkan mortalitas yang tinggi di mana paru-paru belum matang, menghambat bayi bernafas dengan bebas. Pada bayi premature seringkali tidak menghasilkan surfaktan dalam jumlah yang memadai, sehingga alveolinya tidak tetap terbuka di mana antara saat bernapas paru-paru benar-benar mengempis, akibatnya terjadi syndrome distress pernapasan (Manuaba, 2007).

Hasil penelitian ini berbeda dengan hasil penelitian lain sebelumnya, penelitian ini menyatakan bahwa faktor penyebab asiksia mayoritas terjadi pada umur kehamilan ibu 3742 minggu, sedangakan pada penelitian lain mayoritas terjadi asfiksia pada umur kehamilan ibu kurang dari 37 minggu dan umur kehamilan ibu lebih dari 42 minggu.

\section{Faktor Penyebab Kejadian Asfiksia Berdasarkan Faktor Bayi}

\section{a. Berat lahir bayi}

Faktor penyebab kejadian asfiksia selain dipengaruhi dari umur kehamilan juga dapat dipengaruhi dari berat lahir bayi. Hasil penelitian menyatakan bahwa terdapat 12 responden $(38,7 \%)$ yang melahirkan bayi dengan berat $>2500$ gram dan mengalami asfiksia berat yaitu sebanyak $18(58,1 \%)$.

Berat badan lahir merupakan salah satu indikator kesehatan bayi baru lahir. Bayi berat lahir rendah dan bayi berat lahir lebih dimasukkan dalam kelompok risiko tinggi, karena menunjukan angka kematian yang lebih tinggi daripada berat bayi lahir cukup. Bayi berat lahir rendah dan bayi berat lahir lebih merupakan masalah penting dalam pengelolaannya karena mempunyai kecenderungan ke arah peningkatan terjadinya infeksi, asfiksia, ikterus dan hipoglikemi (Manuaba, 2007).

Berat badan lahir bayi merupakan salah satu faktor risiko yang menjadi penyebab utama untuk terjadinya asfiksia neonatorum. Hal ini terlihat dari penelitian yang dilakukan oleh Evi Desfauza8 dari Universitas Sumatera Utara pada tahun 2007 dengan judul "Faktor-faktor yang mempengaruhi asfiksia neonatorum pada bayi baru lahir di RSU Pirngadi Medan" menyatakan bahwa berat badan lahir merupakan salah satu faktor risiko yang berhubungan secara signifikan dan sangat dominan pada kejadian asfiksia neonatorum.
Bayi yang lahir dengan berat badan kurang/lebih memiliki risiko terjadi asfiksia sebesar 79,5\%, sedangkan bayi dengan berat badan normal berisiko sebesar $20,5 \%$.

Hasil penelitian ini berbeda dengan hasil penelitian lain sebelumnya, penelitian ini menyatakan bahwa faktor penyebab asiksia mayoritas terjadi pada berat lahir bayi lebih dari 2500 gram, sedangakan pada penelitian lain mayoritas terjadi pada berat lahir bayi kurang dari 2500 gram.

\section{b. Jenis persalinan}

Penyebab kejadian asfiksia selain dilihat dari faktor ibu dan faktor plasenta juga disebabkan oleh faktor persalinan.Hasil penelitian menyatakan bahwa dari 31 responden terdapat 15 responden dengan jenis persalinan normal melahirkan bayi asfiksia sebanyak 10 $(32,3 \%)$ responden yang melahirkan bayi dengan asfiksia secara SC.

Asfiksia pada persalinan spontan disebabkan karena adanya dari faktor maternal (hipotensi, syok maternal, malnutrisi), faktor uterus (kontraksi memanjang, gangguan vaskuler), faktor tali pusat (prolapsus dan penumbungan tali pusat), dan faktor plasenta (degenerasi vaskuler, solusio plasenta). Jenis persalinan berpengaruh besar terhadap angka kejadian asfiksia neonatorum karena pada persalinan spontan memungkinkan adanya prolapsus tali pusat, kompresi tali pusat juga adanya partus lama yang menyebabkan terjadinya hipoksia pada janin yang menyebabkan tidak ada saluran udara yang akhirnya menyebabkan asfiksia neonatorum. Sedangkan pada persalinan buatan, memungkinkan adanya penggunaan alat-alat medis yang dapat menyebabkan trauma dan perdarahan intra kranial pada bayi dan menghambat sirkulasi oksigen, sesuai dengan teori yang sebelumnya. (JNPK-KR, 2008)

Hasil penelitian yang dilakukan oleh Zulkarnain zainuddin, 2011 yang berjudul "Hubungan jenis persalinan dengan kejadianasfiksia neonatorum di rsup prof. Dr. R.d. kandou manado " menunjukkan adanya hubungan yang bermakna antara jenis persalinan dan asfiksia neonatorum $(\mathrm{P}=000)$, dimana persalinan seksio sesarea dengan presentase terbesar pada bayi asfiksia yakni 31 bayi $(62 \%)$.

Hasil penelitian ini berbeda dengan hasil penelitian lain sebelumnya, penelitian ini menyatakan bahwa faktor penyebab asiksia 
mayoritas terjadi pada jenis persalinan normal, sedangakan pada penelitian lain mayoritas terjadi pada jenis persalinan ibu dengan tindakan seksio sesarea.

\section{KESIMPULAN}

Penelitian ini dilakukan untuk mengetahui Distribusi Frekuensi Faktor Penyebab Kejadian Asfiksia Pada Bayi Baru Lahir di RS Fadhilah Kota Prabumulih tahun 2017. Berdasarkan hasil penelitian kesimpulan yang dapat diambil adalah:

1. Distribusi frekuensi faktor penyebab kejadian asfiksia pada bayi baru lahir berdasarkan faktor ibu yaitu mayoritas terjadi pada usia ibu 20-35 tahun sebanyak $16(51,6 \%)$, paritas multipara $10(32,3 \%)$, umur kehamilan 37-42 minggu 18 $(58,1 \%)$.

2. Distribusi frekuensi faktor penyebab kejadian asfiksia pada bayi baru lahir berdasarkan faktor dari bayi yaitu mayoritas terjadi pada berat lahir bayi $>2500$ gram sebanyak $12(38,7 \%)$, dan jenis persalinan yang mengalami asfiksia pada persalinan normal sebanyak $10(32,3 \%)$.

\section{DAFTAR PUSTAKA}

Arief, dkk. 2011. Neonatus dan Asuhan Keperawatan Anak. Yogyakarta : Nuha Medika

Benson, Pemoll. 2010. Buku Saku Obsetry Gynecology William. Jakarta : EGC

Caroline, Junita. 2014. Faktor- factor yang berhubungan dengan kejadian asfiksia di RSUP Prof. Dr. R. D. Kandou. Manado. Jurnal ilmiah bidan.1:(2).

Danim Darwis. 2010. Metodologi Penelitian Kebidanan : Prosedur, Kebijakan Dan Etik. Jakarta : EGC

Dina Hartatik, Dewi Yuliaswati. 2013. Jurnal Kesehatan Masyarakat: Pengaruh Umur Kehamilan pada Bayi Baru Lahir Dengan Kejadian Asfiksia Di RSUD Dr. Moewardi Surakarta.

Desfauza E. Faktor-faktor yang mempengaruhi asphyxia neonatorum pada bayi baru lahir di RSU Pirngadi Medan. USU Repository 2008.
Dewi, V.N.L. 2010. Asuhan Neonatus Bayi dan Anak Balita. Jakarta : Salemba Medika

Erma Eka Wijaya. 2010. Jurnal Kesehatan Masyarakat : Hubungan Kehamilan Lewat Waktu Dengan Kejadian Asfiksia Bayi Baru lahir Di RSUD. Dr. Koesna Tuban

Henanto, Sori Muda Sarumpaet, Rasmaliah. 2012. Jurnal Kesehatan Masyarakat :Faktor-Faktor Yang Mempengaruhi Asphyxia Neonatorum Di Rumah sakit Elisabeth Medan Tahun 2012.

JNPK-KR. Asuhan Persalinan Normal dan Inisiasi Menyusui Dini. Jakarta:JNPKKR; 2008.

JNPK-KR. Paket Pelatihan Pelayanan Obstetri Dan Neonatal Emergensi Komprehensif (PONEK). Jakarta: JNPK-KR; 2008.

Jurnal Pediatri Online. 2013. Forum Ilmiah kesehatan Anak : Asfiksia, Bayi Tidak Menangis Saat Lahir Dan penanganannya.www.jurnalpediatri.co m, diakses Tanggal 10 Mei 2017

Kementrian Kesehatan Indonesia. 2014. Profil Kesehatan Republik Indonesia Tahun 2014. Jakarta : Kementrian Kesehatan Indonesia

Manuaba I A C. 2007. Buku Pengantar Kuliah Obstetri, Cetakan pertama. : EGC 2010. Ilmu Kebidanan dan Penyakit Kandungan Dan keluarga Berencana Untuk Pendidikan Bidan. Jakarta : EGC

Marmi dan Kukuh. 2012. Asfiksia Pada Bayi Baru Lahir. midwifery.blog.uns.ac.id/asfiksia, diakses tanggal 10 Mei 2017

Maryunani, Anik. 2013. Asuhan Neonatus, Bayi, Balita Dan Anak Pra Sekolah. Jakarta : Trans Info Media. 2013. Buku Saku Asuhan Bayi Dengan Berat Badan lahir rendah. Jakarta : Trans Info Media 
Jurnal Kebidanan : Jurnal Medical Science Ilmu Kesehatan Akademi Kebidanan Budi Mulia Palembang Volume.8 No.2, Desember 2018

Maryunani, A dan Nurhayati. 2012. Asuhan Kegawatdaruratan Dan Penyulit Pada Neonatus. Jakarta : Trans Info Media

Notoadmojo. 2010. Metodologi Penelitian Kesehatan. Jakarta : Rineka Cipta

Novita, Vivian. 2011. Asuhan Neonatus Bayi Dan Anak Balita. Jakarta : Salemba Medika

Pantiawati. 2010. Bayi Dengan Berat Bayi Lahir Rendah. Yogyakarta : Nuha Medika

Prawirohardjo. Buku Acuan Pelayanan Kesehatan Maternal dan Neonatal.Jakarta.:

Yayasan Bina Pustaka Sarwono Prawirohardjo; (2007)

Proverawati dan Cahyo Ismawati. 2010. Berat

Bayi Lahir Rendah. Yogyakarta

Nuha Medika

Purnamaningrum, Y, E. 2010. Penyakit Pada

Neonatus Bayi Dan Balita.

Yogyakarta : Fitramaya

Rika Herawati. 2013. Jurnal Kesehatan masyarakat : Faktor-Faktor Yang Menyebabkan terjadinya Asfksia Neonatorum Pada Bayi Baru lahir Di RSU daerah Kabupaten Rokan Hulu

Rukiyah, dkk. 2010. Asuhan Kebidanan dan kehamilan. Jakarta : Trans Info Media. 2010. Asuhan Kebdanan II Persalinan. Jakarta : CV. Trans Media

Safrina. 2011. Jurnal Kesehatan Masyarakat: Dampak Asfiksia Pada

Medan Bayi Baru Lahir. Sumatra Utara :

Sholihah. 2010. Persiapan Persalinan Dan

Kelahiran Bayi. Jakarta : EGC

Ummul Mahmudah, dkk. 2011. Jurnal Kesehatan Masyarakat : Faktor Ibu Dan Bayi Yan g Berhubungan dengan

Kejadian kematian Perinatal. JKM http://journal.unnes.ac.id/index.php /kemas, diakses Tanggal 10 Mei 2017

Wiknjosastro. 2007. Ilmu Kebidanan. Jakarta.: Yayasan Bina Pustaka Sarwono Prawirohardjo. 
